\title{
PENYELIDIKAN STRUKTUR BATUAN MENGGUNAKAN METODA GEOLISTRIK TAHANAN JENIS KONFIGURASI WENNER INVERSI ROBUST CONSTRAINT DI JORONG KOTO BARU NAGARI AIE DINGIN KABUPATEN SOLOK
}

\author{
Sri mulyani ${ }^{1)}$, Akmam ${ }^{2)}$ dan Harman Amir ${ }^{2)}$ \\ ${ }^{1)}$ Mahasiswa Jurusan Fisika FMIPA UNP \\ ${ }^{2)}$ Staf Pengajar Jurusan Fisika FMIPA UNP \\ $\underline{\text { mulyani12sri@gmail.com }}^{1)}$, akmamdb@fmipa.unp.ac.id ${ }^{2)}$ dan harman_unp.@yahoo.com ${ }^{3)}$
}

\begin{abstract}
Rock structure in Jorong Koto Baru has not been known and analyzed. Furthermore, it is significant to conduct a research which was purposed to find the structure of rock in Jorong Koto Baru, Nagari Aie Dingin, Kabupaten Solok. The measurement used Resistivity Geoelectrical method with Wenner Configuration. The data were analyzed and interpreted by using Robust Constrain Inversion in software Res2dinv to obtain 2D model. This research indicated that there are five types of rocks which had formed in Jorong Koto Baru, Nagari Aie Dingin, Kabupaten Solok. They are Sands, Clay, Sandstone, Limestone, and Granite. Sandstone, Limestone and Clay dominate rock structure in Jorong Koto Baru.
\end{abstract}

Keywords : Resistivity Geoelectrical, Rock Structure, Wenner

\section{PENDAHULUAN}

Jorong Koto Baru Nagari Aie Dingin Kecamatan Lembah Gumanti Kabupaten Solok bertopografi gelombang dan lereng sehingga berpotensi terhadap gerakan tanah. Longsor tahun 2006 dan tahun 2015 di daerah Jorong Koto Baru mengakibatkan masyarakat mengalami kerugian signifikan $^{[1][2]}$. Kerugian akibat longsor di Jorong Koto Baru seharusnya dapat diminimalisir dengan mempelajari penyebab dan gejala terjadi longsor. Longsor terjadi akibat pergerakan tanah pada lereng yang curam. Gerakan tanah disebabkan oleh beberapa faktor antara lain penggunaan lahan yang tidak teratur, curah hujan, kemiringan permukaan tanah, tanah yang kurang padat, dan struktur batuan $\operatorname{lapuk}^{[3]}$.

Upaya yang dilakukan untuk mengantisipasi dan meminimalisir kerugian akibat bencana longsor adalah mengetahui kondisi batuan penyusun lereng. Informasi kondisi batuan penyusun lereng didapatkan dengan mengetahui struktur batuan. Struktur batuan menentukan kondisi bawah permukaan bumi. Struktur batuan dapat digunakan untuk mengidentifikasi patahan bawah permukaan bumi dan menentukan kestabilan batuan penyusun bawah permukaan bumi. Struktur batuan bawah permukaan bumi dibutuhkan dalam perencanaan pondasi bangunan sehingga dapat meminimalisasi resiko terhadap kerusakan akibat gempa dan gerakan $\operatorname{tanah}^{[6]}$. Struktur batuan yang menyebabkan gerakan tanah yaitu struktur batuan yang labil di lereng. Struktur batuan yang labil adalah lapisan batuan yang tersusun dari lapisan batuan lapuk yang menghasilkan mineral lempung ${ }^{[7]}$. Struktur batuan di Jorong Koto Baru sudah diteliti sebelumnya ${ }^{[4][5]}$. Hasil penelitian sebelumnya menunjukkan struktur batuan di daerah Jorong Koto Baru terdiri dari Alluvium and Sands, Sandstone, Clay, Limestone, dan Granite. Hasil penelitian juga menyimpulkan bahwa bentuk bidang gelincir pemicu terjadinya tanah longsor di daerah Jorong Koto Baru berupa Translation Slip ${ }^{[4]}$. Lapisan batuan yang berperan sebagai bidang gelincir di daerah Jorong Koto Baru adalah batuan Clay.

Batuan adalah zat padat yang terdiri dari kumpulan satu atau beberapa mineral. Batuan terbentuk dari pembekuan magma panas dan mengeras karena pendinginan. Batuan yang dihasilkan dari proses pendinginan magma disebut batuan beku. Pada awalnya seluruh bagian bumi terdiri dari batuan beku ${ }^{[8]}$. Seiring dengan perjalanan waktu serta pengaruh lingkungan, terjadilah perubahan-perubahan pada batuan beku yang membentuk kelompok-kelompok batuan yang lainnya yaitu batuan Sedimen dan Metamorf.

Struktur batuan dieksplorasi berdasarkan nilai resistivitas yang diperoleh. Nilai resistivitas dipelajari dengan menginjeksikan arus listrik ke dalam bumi dan mengukur beda potensial di permukaan bumi ${ }^{[9]}$. Metoda Geolistrik Tahanan Jenis digunakan untuk eksplorasi kebumian dengan mendeteksi tahanan jenis batuan ${ }^{[10]}$. Tujuan pengukuran dengan metode Geolistrik adalah untuk mengetahui jenis batuan perlapisan berdasarkan distribusi nilai tahanan jenis. 
Metode Geolistrik Tahanan Jenis didasarkan dengan anggapan bahwa bumi mempunyai sifat homogen isotropis. Hal ini menyebabkan sebaran aliran arus hanya ke bawah permukaan bumi dengan equipotensial berbentuk setengah bola seperti pada Gambar 1.

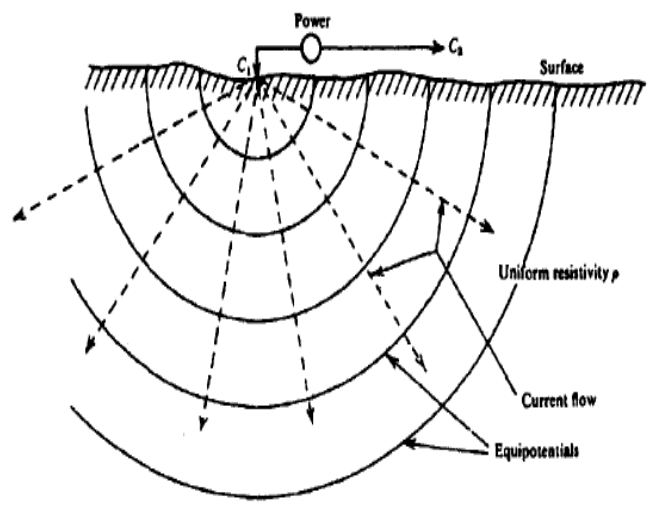

Gambar 1.Arus dan Garis Equipotensial yang Dihasilkan oleh Satu Titik di Permukaan $^{[12]}$

Tahanan jenis yang didapat dari pengukuran metode Geolistrik Tahanan Jenis bukan tahanan jenis sesungguhnya melainkan tahanan jenis semu (apparent resitivity, $\left.\rho_{a}\right)^{[13]}$. Nilai tahanan jenis semu dirumuskan dengan persamaan (1) berikut.

$$
\rho_{a}=K \frac{\Delta V}{I}
$$

dimana $\rho_{a}$ merupakan nilai tahanan jenis semu, $\Delta V$ merupakan nilai beda potensial, $I$ merupakan nilai arus, dan $K$ merupakan faktor geometri yang harganya bergantung pada konfigurasi yang digunakan. Metode Geolistrik memiliki banyak konfigurasi salah satunya adalah konfigurasi konfigurasi Wenner.

Konfigurasi Wenner sangat sensitif dalam mendeteksi ketidakhomogenan lapisan bawah permukaan bumi secara lateral. Konfigurasi Wenner mempunyai keunggulan dalam tingkat sensitivitas terhadap pengaruh ketidakhomogenan material di bawah permukaan bumi secara lateral, memiliki resolusi vertikal yang bagus serta dapat menentukan variasi nilai tahanan jenis secara horizontal ${ }^{[12]}$. Konfigurasi Wenner menggunakan empat elektroda yaitu elektroda arus dan elektroda potensial dengan susunan jarak antar elektroda sama panjang. Susunan elektroda konfigurasi Wenner mirip dengan susunan elektroda konfigurasi Schlumberger, akan tetapi jarak elektroda pada konfigurasi Wenner sama panjang ${ }^{[14]}$. Susunan elektroda konfigurasi Wenner dapat dilihat pada Gambar 2.

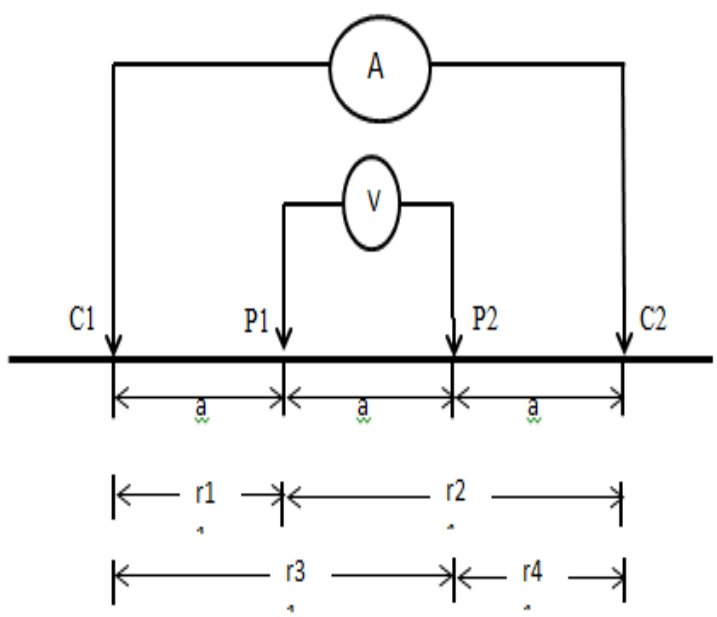

Gambar 2. Bentuk Umum Konfigurasi Elektroda Wenner

Gambar 2 menunjukkan susunan elektroda konfigurasi Wenner Geolistrik menggunakan dua elektroda arus yang dilambangkan dengan $\mathrm{C}$ dan dua elektroda potensial yang dilambangkan dengan $\mathrm{P}$. Nilai faktor geometri dapat dirumuskan dengan Persamaan (2) berikut.

$$
k=2 \pi a(2)
$$

Nilai tahanan jenis semu untuk metoda Geolistrik konfigurasi Wenner dapat dirumuskan dengan persamaan (3).

$$
\rho=K \frac{\Delta V}{I}=2 \pi a \frac{\Delta V}{I}(3)
$$

Interpretasi data dilakukan menggunakan metoda inversi Robust Constraint. Inversi Robust Constraint bertujuan untuk mempermudah dalam proses pengolahan data sehingga meningkatkan keakuratan interpretasi data penelitian. Inversi Robust Constraint memberikan hasil yang baik dalam menggambarkan model resistivitas pada daerah yang memiliki batas lapisan yang tajam dibandingkan Inversi Least Square ${ }^{[15]}$. Metode Inversi Robust Constraint baik digunakan untuk menghasilkan pencitraan lapisan geologi bawah permukaan bumi. Inversi Robust Constraint dirumuskan dengan persamaan (4).

$$
\left(J^{T} J+\lambda F_{R}\right) \Delta q=J^{T} R_{d} g-\lambda F_{R} q(4)
$$

dimana $J$ adalah matrik Jacobian dari turunan parsial, $\mathrm{R}_{\mathrm{d}}$ adalah pembobot untuk mempertajam batasan antar lapisan, $\lambda$ adalah faktor damping yang berfungsi untuk mempercepat proses konvergensi , $\Delta \mathrm{q}$ adalah vektor perubahan parameter model dan $\mathrm{g}$ merupakan vektor discrepancy yaitu vektor ketidakcocokan hasil pengukuran dengan model atau vektor perbedaan antara nilai-nilai tahanan jenis pengukuran dan perhitungan.

Tujuan penelitian ini adalah menentukan struktur batuan untuk mengurangi kerugian akibat longsor di Jorong Koto Baru. Berdasarkan uraian di atas telah dilakukan penelitian mengenai 
penyelidikan struktur batuan menggunakan metoda Geolistrik Tahanan Jenis Konfigurasi Wenner Inversi Robust Constraint di Jorong Koto Baru Nagari aie Dingin Kabupaten Solok. Hasil penelitian berguna untuk mengantisipasi kerugian akibat longsor di Jorong Koto Baru.

\section{METODE PENELITIAN}

Parameter penelitian terdiri dari parameter ukur merupakan parameter yang diperoleh langsung pada saat pengukuran dilapangan yaitu (kuat arus listrik (I), beda potensial (V) dan spasi elektroda). Parameter hitung ( tahanan jenis semu $\left(\rho_{a}\right)$ batuan). Parameter yang diinterpretasikan yaitu nilai tahanan jenis ( $\rho$ ) sesungguhnya dan kedalaman). Parameter yang diestimasi yaitu strukur batuan.

Penelitian menggunakan empat lintasan pengukuran. Desain Lintasan pengukuran terlihat pada Gambar 3.

Gambar 3. Desain Lintasan Pengukuran

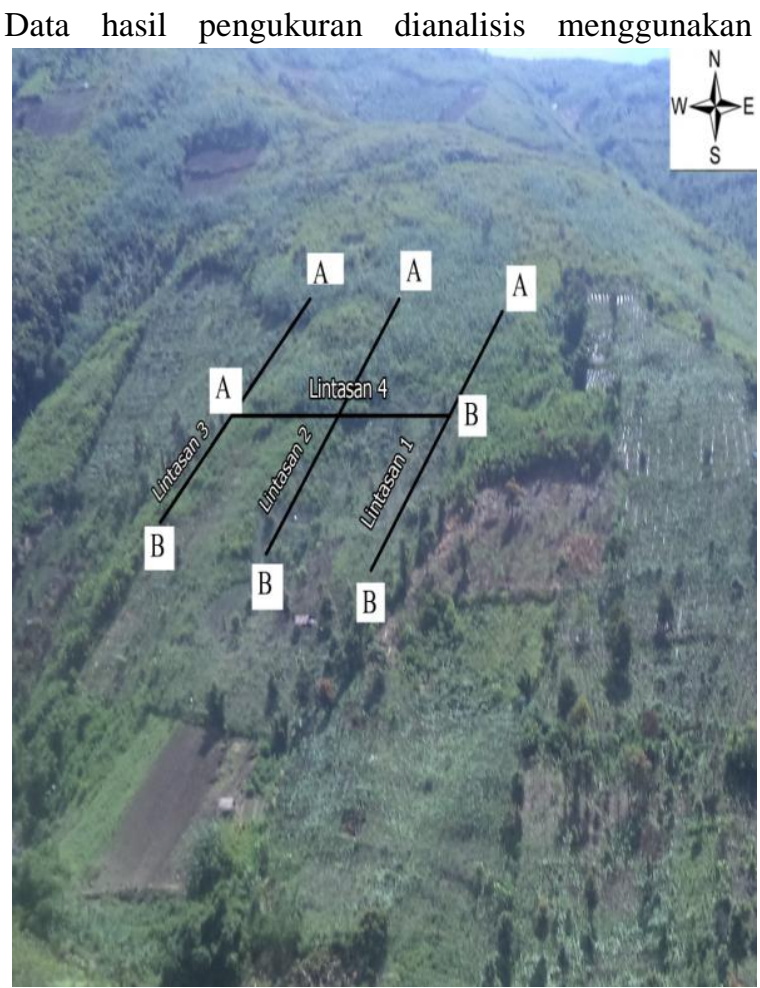

persamaan (3) sehingga didapatkan nilai tahanan jenis semu. Tahanan jenis semu diinterpretasi menggunakan persamaan (4). Inerpretasi data menghasilkan penampang 2D bawah permukaan Jorong Koto Baru Nagari Aie Dingin. Berdasarkan penampang 2D diketahui nilai tahanan jenis sebenarnya dan kedalaman. Nilai tahanan jenis sebenarnya dibandingkan dengan nilai tahanan jenis pada tabel tahanan jenis serta kondisi Geologi daerah penelitian, sehingga diperoleh kesimpulan mengenai kedalaman dan jenis batuan di daerah penelitian. Jenis batuan dan kedalaman yang diperoleh pada saat interpretasi data diperlukan untuk menentukan struktur batuan.

\section{HASIL PENELITIAN DAN PEMBAHASAN}

\section{A. Hasil Penelitian}

1. Lintasan 1

Lintasan 1 terletak pada koordinat $01^{\circ} 11^{\prime} 24.0^{\prime \prime}$ LS dan $100^{\circ} 48^{\prime} 53.2^{\prime \prime}$ BT sampai $01^{\circ} 11^{\prime} 14.9^{\prime \prime}$ LS dan $100^{\circ} 48^{\prime} 53.2^{\prime \prime}$ BT. Titik sounding Lintasan 1 pada koordinat $00^{\circ} 11^{\prime} 19.4^{\prime \prime}$ LS dan $100^{\circ} 48^{\prime} 53.5^{\prime \prime}$ BT. Panjang Lintasan 1 adalah $315 \mathrm{~m}$ dengan jarak spasi elektroda $5 \mathrm{~m}$. Gambar 10 menunjukkan penampang 2D hasil pengolahan data Lintasan 1 dengan inversi Robust Constrain.

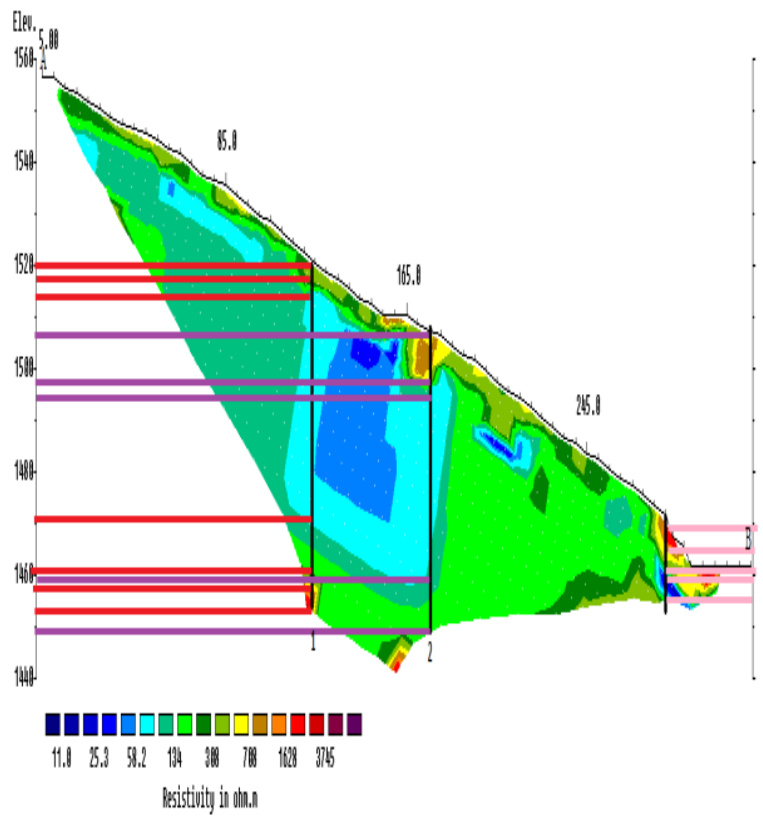

Gambar 4. Penampang Model 2D Lintasan 1 dengan Topografi

Gambar 4 memperlihatkan penampang 2D bawah permukaan sepanjang Lintasan 1 dengan ketinggian berkisar antara 1435 - 1555 mdpl. A merupakan titik awal pengukuran dan B merupakan titik akhir pengukuran. Ketinggian maksimum yang dapat dideteksi yaitu $1560 \mathrm{~m}$. Distribusi nilai tahanan jenis Lintasan1 berkisar antara 13,23 $\Omega \mathrm{m}-$ $3625,90 \Omega \mathrm{m}$ dengan persentase kesalahan (error) yang diperoleh pada iterasi ke 7 sebesar $2,1 \%$, hal ini menunjukkan bahwa tingkat keakuratan hasil penelitian sekitar 97,9\%.

Lintasan 1 diidentifikasi memiliki 5 jenis lapisan batuan penyusun. Nilai tahanan jenis dengan rentang 13,23 $\Omega \mathrm{m}-25,3 \Omega \mathrm{m}$ diidentifikasi sebagai Alluvium and sands. Nilai tahanan jenis dari rentang 25,1 $\Omega \mathrm{m}-96,01 \Omega \mathrm{m}$ diidentifikasi sebagai Clay. Lapisan dengan nilai tahanan jenis 96,01 $\Omega \mathrm{m}-308 \Omega \mathrm{m}$ diidentifikasi sebagai Sandstone. Lapisan dengan rentangan nilai tahanan jenis berkisar antara $308 \Omega \mathrm{m}-1168,19 \Omega \mathrm{m}$ diidentifikasi sebagai Limestone. Lapisan dengan nilai tahanan jenis lebih besar diidentifikasikan sebagai Granite dengan nilai tahanan jenis berkisar antara $1168,19 \Omega \mathrm{m}-3625,90 \Omega \mathrm{m}$ 
Berdasarkan Gambar 4 terdapat 3 titik untuk mengidentifikasi jenis batuan pada Lintasan 1 . Identifikasi jenis batuan, ketinggian, dan ketebalan lapisan batuan sepanjang Lintasan 1 diambil pada 3 titik sounding. Titik sounding yang diambil memiliki variasi nilai resistivity yang dapat dianggap mewakili lapisan batuan pada Lintasan 1. Titik 1 berada pada jarak $123 \mathrm{~m}$ dengan koordinat $01^{\circ} 11^{\prime} 24.0^{\prime \prime}$ LS dan $100^{\circ} 48^{\prime} 53.8^{\prime \prime}$ BT. Titik 1 diidentifikasi memiliki 4 jenis lapisan batuan yaitu Clay, Sandstone, Limestone, dan Granite dan tidak ditemukan jenis lapisan Alluvium and Sands. Lapisan Clay terdapat pada ketinggian 1472,2 m sampai ketinggian 1516,8 m dengan ketebalan 44,6 m. Selanjutnya lapisan Sandstone dari ketinggian 1516,8 sampai ketinggian 1519,8 m dengan ketebalan 3 m dan pada ketinggian 1462 m sampai ketinggian 1472,2 m dengan ketebalan 10,2 m. Lapisan Limestone terdapat pada ketinggian 1519,8 m sampai ketinggian 1521,8 m dengan ketebalan $2 \mathrm{~m}$ dan pada ketinggian 1459 m sampai ketinggian 1462 $\mathrm{m}$ dengan ketebalan $3 \mathrm{~m}$. Lapisan Granite terdapat pada ketinggian $1454 \mathrm{~m}$ sampai ketinggian $1459 \mathrm{~m}$ dengan ketebalan $5 \mathrm{~m}$.

Titik 2 berada pada jarak $170 \mathrm{~m}$ tepatnya pada titik sounding dengan koordinat $01^{\circ} 11^{\prime} 18.9^{\prime \prime} \mathrm{LS}$ dan $100^{\circ} 48^{\prime} 53.4^{\prime \prime} \mathrm{BT}$. Titik ini diidentifikasi memiliki 3 jenis lapisan batuan yaitu Clay, Sandstone,dan Limestone. Lapisan Clay terdapat pada ketinggian 1558 m sampai ketinggian 1595 m dengan ketebalan $37 \mathrm{~m}$. Lapisan Sandstone terdapat pada ketinggian 1595 m sampai ketinggian 1597 m dengan ketebalan $2 \mathrm{~m}$ dan pada ketinggian $1550 \mathrm{~m}$ sampai ketinggian $1558 \mathrm{~m}$ dengan ketebalan $8 \mathrm{~m}$. Lapisan Limestone terdapat pada ketinggian 1597,5 m sampai ketinggian 1606,8 $\mathrm{m}$ dengan ketebalan $9 \mathrm{~m}$.

Titik 3 yang berada pada jarak $280 \mathrm{~m}$ terletak pada koordinat $01^{\circ} 11^{\prime} 19.0^{\prime \prime}$ LS dan $100^{\circ} 48^{\prime} 52.2^{\prime \prime}$ BT. Titik ini diidentifikasi memiliki 4 jenis lapisan batuan yaitu Aluvium and Sands, Clay, Limestone, dan Granite. Lapisan Aluvium and Sands berada pada ketinggian 1455 m sampai ketinggian $1458 \mathrm{~m}$ dengan ketebalan $3 \mathrm{~m}$. Lapisan Clay terdapat pada ketinggian 1458 m sampai ketinggian 1460 m dengan ketebalan $2 \mathrm{~m}$. Lapisan Limestone terdapat pada ketinggian 1460 m sampai ketinggian 1465 m dengan ketebalan $5 \mathrm{~m}$. Lapisan Granite terdapat pada ketinggian 1465 m sampai pada ketinggian $1470 \mathrm{~m}$ dengan ketebalan $5 \mathrm{~m}$.

\section{Lintasan 2}

Lintasan 2 terletak pada koordinat $01^{\circ} 11^{\prime} 25.6^{\prime \prime}$ LS dan $100^{\circ} 48^{\prime} 52.9^{\prime \prime}$ BT menuju ke arah utara dengan koordinat $01^{\circ} 11^{\prime} 20.7^{\prime \prime}$ LS dan $100^{\circ} 49^{\prime} 00.6^{\prime \prime}$ BT. Titik sounding Lintasan 2 pada koordinat 00¹1'22.7" LS dan 10048'56.2" BT. Penampang 2D hasil pengolahan data Lintasan 2 dengan Inversi Robust Constrain 0,001 ditunjukkan pada Gambar 5.

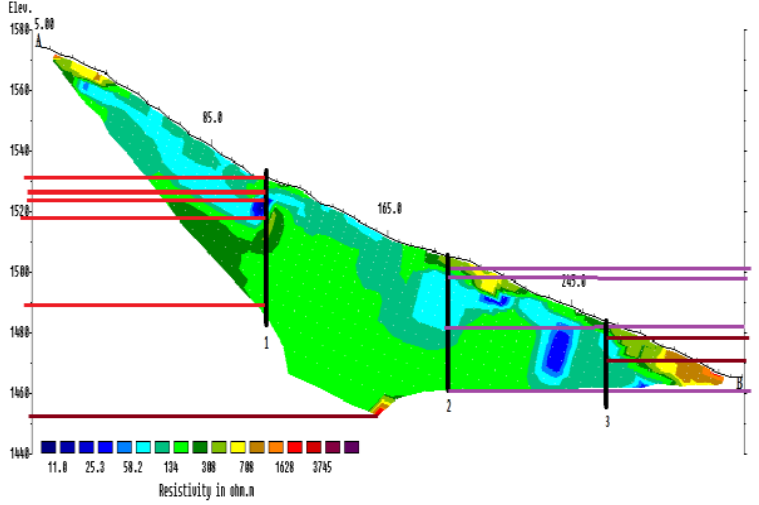

Gambar 5. Penampang Model 2D Lintasan 2 dengan Topografi

Gambar 5 memperlihatkan penampang 2D bawah permukaan sepanjang Lintasan 2 dengan ketinggian berkisar antara 1468 - 1578 mdpl. A merupakan titik awal pengukuran dan B merupakan titik akhir pengukuran. Ketinggian maksimum yang dapat dideteksi yaitu $1580 \mathrm{~m}$. Distribusi nilai tahanan jenis Lintasan 2 berkisar antara 10,55 $\Omega \mathrm{m}-1168,19$ $\Omega \mathrm{m}$ dengan persentase kesalahan (error) yang diperoleh pada iterasi ke 7 sebesar 2,3\%, hal ini menunjukkan bahwa tingkat keakuratan hasil penelitian sekitar $97,7 \%$.

Lintasan 2 diidentifikasi memiliki 4 jenis lapisan batuan penyusun. Nilai tahanan jenis dengan rentang 10,55 $\Omega \mathrm{m}-25.3 \Omega \mathrm{m}$ diidentifikasi sebagai Alluvium and sands. Nilai tahanan jenis dari rentang $25,1 \Omega \mathrm{m}-96,01$. Lapisan dengan nilai tahanan jenis 96,01 $\Omega \mathrm{m}-308 \Omega \mathrm{m}$ diidentifikasi sebagai Sandstone. Lapisan dengan rentangan nilai tahanan jenis berkisar antara $308 \Omega \mathrm{m}-1168,19 \Omega \mathrm{m}$ diidentifikasi sebagai Limestone.

Identifikasi jenis batuan, ketinggian, dan ketebalan lapisan batuan sepanjang Lintasan 2 diambil pada 3 titik sounding.

Titik 1 berada pada jarak $110 \mathrm{~m}$ dengan koordinat $01^{\circ} 11^{\prime} 23.5^{\prime \prime}$ LS dan $100^{\circ} 48^{\prime} 52.2^{\prime \prime}$ BT. Titik ini diidentifikasi memiliki 3 jenis lapisan batuan yaitu Alluvium and Sands, Clay, dan Sandstone, pada titik ini tidak ditemukan jenis lapisan Limestone. Lapisan Alluvium and Sands terdapat pada ketinggian $1451 \mathrm{~m}$ sampai ketinggian $1546 \mathrm{~m}$ dengan ketebalan $5 \mathrm{~m}$. Lapisan Clay terdapat pada ketinggian $1546 \mathrm{~m}$ sampai ketinggian $1548 \mathrm{~m}$ dengan ketebalan $2 \mathrm{~m}$. Selanjutnya lapisan Sandstone dari ketinggian 1539 m sampai ketinggian $1546 \mathrm{~m}$ dengan ketebalan $7 \mathrm{~m}$ dan pada ketinggian 1546 m sampai ketinggian 1541 $\mathrm{m}$ dengan ketebalan $28 \mathrm{~m}$.

Titik 2 berada pada jarak $190 \mathrm{~m}$ tepatnya pada titik sounding dengan koordinat $01^{\circ} 11^{\prime} 22.0^{\prime \prime}$ LS dan $100^{\circ} 48^{\prime} 52.9^{\prime \prime}$ BT. Titik ini diidentifikasi memiliki 3 jenis lapisan batuan yaitu Clay, Sandstone dan Limestone. Lapisan Clay terdapat pada ketinggian $1486 \mathrm{~m}$ sampai ketinggian $1502 \mathrm{~m}$ dengan ketebalan $16 \mathrm{~m}$. Lapisan Sandstone terdapat pada ketinggian 1464 m sampai ketinggian 1486 m dengan ketebalan $22 \mathrm{~m}$. Lapisan Limestone terdapat pada ketinggian 
1486 m sampai ketinggian 1490 m dengan ketebalan $4 \mathrm{~m}$.

Titik 3 yang berada pada jarak $245 \mathrm{~m}$ dengan koordinat $01^{\circ} 11^{\prime} 21.1^{\prime \prime} \mathrm{LS}$ dan $100^{\circ} 48^{\prime} 58.0^{\prime \prime} \mathrm{BT}$. Titik ini diidentifikasi memiliki 3 jenis lapisan batuan yaitu, Clay, Sandstone dan Limestone. Lapisan Clay terdapat pada ketinggian $1470 \mathrm{~m}$ sampai ketinggian $1478 \mathrm{~m}$ dengan ketebalan $8 \mathrm{~m}$. Lapisan Sandstone terdapat pada ketinggian $1464 \mathrm{~m}$ sampai ketinggian $1470 \mathrm{~m}$ dengan ketebalan $6 \mathrm{~m}$. Lapisan Limestone terdapat pada ketinggian $1478 \mathrm{~m}$ sampai ketinggian $1495 \mathrm{~m}$ dengan ketebalan $17 \mathrm{~m}$.

\section{Lintasan 3}

Lintasan 3 terletak pada koordinat $01^{\circ} 11^{\prime} 28.4^{\prime \prime}$ LS dan $100^{\circ} 48^{\prime} 59.5^{\prime \prime}$ BT menuju ke arah utara dengan koordinat $01^{\circ} 11^{\prime} 21.9^{\prime \prime} \mathrm{LS}$ dan $100^{\circ} 49^{\prime} 05.8^{\prime \prime}$ BT. Titik sounding Lintasan 3 pada koordinat $00^{\circ} 11^{\prime}$ 25.6" LS dan 100'49'03.0" BT. Gambar 12 menunjukkan penampang 2D hasil pengolahan data Lintasan 3 dengan inversi Robust Constrain 0,001 ditunjukkan pada Gambar 6 .

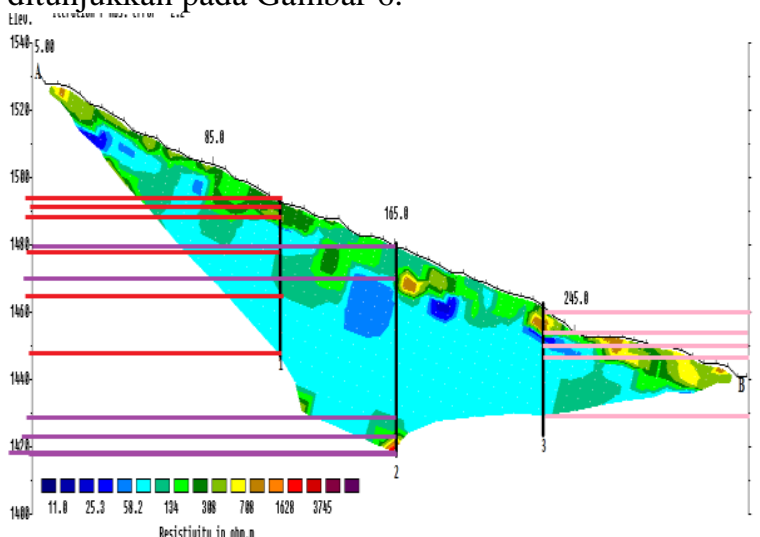

Gambar 6. Penampang Model 2D Lintasan 3 dengan Topografi

Gambar 6 memperlihatkan penampang 2D bawah permukaan sepanjang Lintasan 3 dengan ketinggian berkisar antara 1440 - 1528 mdpl. A merupakan titik awal pengukuran dan B merupakan titik akhir pengukuran. Ketinggian maksimum yang dapat dideteksi yaitu $1540 \mathrm{~m}$. Distribusi nilai tahanan jenis Lintasan2 berkisar antara 20,42 $\Omega \mathrm{m}-3040,80$ $\Omega \mathrm{m}$ dengan persentase kesalahan (error) yang diperoleh pada iterasi ke 7 sebesar 2,2\%, hal ini menunjukkan tingkat keakuratan hasil penelitian sekitar $97,8 \%$.

Lintasan 3 diidentifikasi memiliki 5 jenis lapisan batuan penyusun. Nilai tahanan jenis dengan rentang 20,42 $\Omega \mathrm{m}-25,3 \Omega \mathrm{m}$ diidentifikasi sebagai Alluvium and Sands. Nilai tahanan jenis dari rentang 25,1 $\Omega \mathrm{m}-96,01 \Omega \mathrm{m}$ diidentifikasi sebagai Clay. Lapisan dengan nilai tahanan jenis $96,01 \Omega \mathrm{m}-$ $308 \Omega \mathrm{m}$ diidentifikasi sebagai Sandstone. Lapisan dengan rentangan nilai tahanan jenis berkisar antara $308 \Omega \mathrm{m}-1168,19 \Omega \mathrm{m}$ diidentifikasi sebagai
Limestone. Lapisan dengan nilai tahanan jenis lebih besar diidentifikasikan sebagai Granite dengan nilai tahanan jenis berkisar antara 1168,19 $\Omega \mathrm{m}-3040,80$ $\Omega \mathrm{m}$.

Identifikasi jenis batuan, ketinggian, dan ketebalan lapisan batuan sepanjang Lintasan 3 diambil pada 3 titik sounding. Titik sounding yang diambil terdiri dari 1 sounding utama dan 2 sounding lainnya memiliki variasi nilai resistivity yang dapat dianggap mewakili lapisan batuan pada Lintasan 3 . Titik 1 berada pada jarak $115 \mathrm{~m}$ dengan koordinat $01^{\circ} 11^{\prime} 26.6^{\prime \prime}$ LS dan 100'48'59.3" BT. Titik ini diidentifikasi memiliki 3 jenis lapisan batuan yaitu Clay, Sandstone dan Limestone dan tidak ditemukan jenis lapisan Alluvium and Sands dan Granite. Lapisan Clay terdapat pada ketinggian $1454 \mathrm{~m}$ sampai ketinggian $1464 \mathrm{~m}$ dengan ketebalan $10 \mathrm{~m}$ dan pada ketinggian 1479 m sampai ketinggian 1496 $\mathrm{m}$ dengan ketebalan $17 \mathrm{~m}$. Lapisan Sandstone dari ketinggian $1448 \mathrm{~m}$ sampai ketinggian $1451 \mathrm{~m}$ dengan ketebalan $3 \mathrm{~m}$ dan pada ketinggian $1464 \mathrm{~m}$ sampai ketinggian 1479 m dengan ketebalan $13 \mathrm{~m}$. Selanjutnya lapisan Limestone terdapat pada ketinggian $1451 \mathrm{~m}$ sampai ketinggian $1454 \mathrm{~m}$ dengan ketebalan $3 \mathrm{~m}$.

Titik 2 berada pada jarak $166 \mathrm{~m}$ koordinat $01^{\circ} 11^{\prime} 25.3^{\prime \prime}$ LS dan $100^{\circ} 48^{\prime} 03.0^{\prime \prime}$ BT tepatnya pada titik sounding. Titik ini diidentifikasi memilki 4 jenis lapisan batuan yaitu Clay, Sandstone, Limestone, dan Granite. Lapisan Clay terdapat pada ketinggian 1428 m sampai ketinggian 1470 m dengan ketebalan $42 \mathrm{~m}$. Lapisan Sandstone terdapat pada ketinggian $1470 \mathrm{~m}$ sampai ketinggian $1480 \mathrm{~m}$ dengan ketebalan $10 \mathrm{~m}$ dan pada ketinggian 1423 m sampai ketinggian 1428 m dengan ketebalan $5 \mathrm{~m}$. Lapisan Limestone terdapat pada ketinggian 1420 m sampai ketinggian 1423 m dengan ketebalan $3 \mathrm{~m}$. Lapisan Granite terdapat pada ketinggian 1418 m sampai ketinggian 1420 m dengan ketebalan $2 \mathrm{~m}$.

Titik 3 yang berada pada jarak $230 \mathrm{~m}$ koordinat $01^{\circ} 11^{\prime} 23.6^{\prime \prime}$ LS dan $100^{\circ} 48^{\prime} 04.1^{\prime \prime}$ BT. Titik 3 diidentifikasi memiliki 3 jenis lapisan batuan yaitu, Alluvium and Sands, Sandstone dan Limestone. Lapisan Alluvium and Sands terdapat pada ketinggian 1432 m sampai ketinggian 1434 m dengan ketebalan $2 \mathrm{~m}$. Lapisan Sandstone terdapat pada ketinggian 1428 m sampai ketinggian 1432 m dengan ketebalan $4 \mathrm{~m}$ dan pada ketinggian $1434 \mathrm{~m}$ sampai ketinggian 1437 m dengan ketebalan $3 \mathrm{~m}$. Lapisan Limestone terdapat pada ketinggian $1437 \mathrm{~m}$ sampai ketinggian $1442 \mathrm{~m}$ dengan ketebalan $5 \mathrm{~m}$.

\section{Lintasan 4}

Lintasan 4 terletak pada koordinat $01^{\circ} 11^{\prime} 20.7^{\prime \prime}$ LS dan $100^{\circ} 48^{\prime} 54.1^{\prime \prime}$ BT menuju ke arah barat dengan koordinat $01^{\circ} 11^{\prime} 27.9^{\prime \prime}$ LS dan $100^{\circ} 45^{\prime} 00.7^{\prime \prime}$ BT. Titik sounding Lintasan 4 pada koordinat $00^{\circ} 11^{\prime}$ 24.9" LS dan $100^{\circ} 49^{\prime} 56.8^{\prime \prime}$ BT. Penampang 2D hasil 
pengolahan data Lintasan 1 dengan inversi Robust Constrain 0,001 ditunjukkan pada Gambar 7.

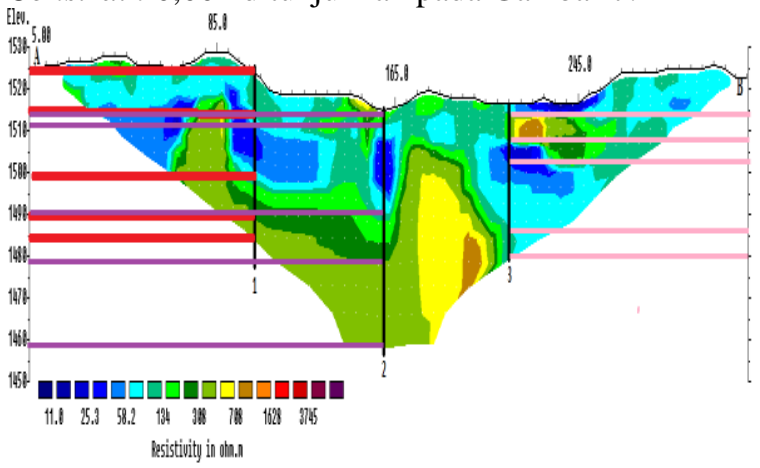

Gambar 7. Penampang Model 2D Lintasan 4 dengan Topografi

Gambar 7 memperlihatkan penampang 2D bawah permukaan sepanjang Lintasan 4 dengan ketinggian berkisar antara 1450 - 1525 mdpl. A merupakan titik awal pengukuran dan B merupakan titik akhir pengukuran Ketinggian maksimum yang dapat dideteksi yaitu $1530 \mathrm{~m}$. Distribusi nilai tahanan jenis Lintasan 4 berkisar antara 11,89 $\Omega \mathrm{m}-1665,70$ $\Omega \mathrm{m}$ dengan persentase kesalahan (error) yang diperoleh pada iterasi ke 7 sebesar $3 \%$, hal ini menunjukkan tingkat keakuratan hasil penelitian sekitar $97 \%$.

Lintasan 4 diidentifikasi memiliki 4 jenis lapisan batuan penyusun. Nilai tahanan jenis dengan rentang 11,89 $\Omega \mathrm{m}-25,3 \Omega \mathrm{m}$ diidentifikasi sebagai Alluvium and sands. Nilai tahanan jenis dari rentang 25,3 $\Omega \mathrm{m}-96,01 \Omega \mathrm{m}$ diidentifikasi sebagai Clay. Lapisan dengan nilai tahanan jenis $96,01 \Omega \mathrm{m}-$ $308 \Omega \mathrm{m}$ diidentifikasi sebagai Sandstone. Lapisan dengan rentangan nilai tahanan jenis berkisar antara $308 \Omega \mathrm{m}-1165,70 \Omega \mathrm{m}$ diidentifikasi sebagai Limestone

Identifikasi jenis batuan, ketinggian, dan ketebalan lapisan batuan sepanjang Lintasan 4 diambil pada 3 titik sounding. Titik sounding yang diambil memiliki variasi nilai resistivity yang dapat dianggap mewakili lapisan batuan pada Lintasan 4 . Berdasarkan Gambar 7 terdapat 3 titik untuk mengidentifikasi jenis batuan pada Lintasan 4 .

titik 1 yang berada pada jarak $103 \mathrm{~m}$ dengan $01^{\circ} 11^{\prime} 23.5^{\prime \prime} \mathrm{LS}$ dan $100^{\circ} 48^{\prime} 54.2^{\prime \prime} \mathrm{BT}$ terdapat 3 jenis lapisan batuan yaitu Clay, Sandstone dan Limestone. Lapisan Clay terdapat pada kedalaman $1510 \mathrm{~m}$ sampai ketinggian $1525 \mathrm{~m}$ dengan ketebalan $15 \mathrm{~m}$. Lapisan Sandstone dari ketinggian $1525 \mathrm{~m}$ sampai ketinggian $1535 \mathrm{~m}$ dengan ketebalan $10 \mathrm{~m}$ dan pada ketinggian $1500 \mathrm{~m}$ sampai ketinggian $1510 \mathrm{~m}$ dengan ketebalan $10 \mathrm{~m}$. Selanjutnya lapisan Limestone terdapat pada ketinggian 1510 m sampai ketinggian $1500 \mathrm{~m}$ dengan ketebalan $15 \mathrm{~m}$.

Titik 2 berada pada jarak $165 \mathrm{~m} \mathrm{01}^{\circ} 11^{\prime} 25.2^{\prime \prime}$ LS dan $100^{\circ} 48^{\prime 25}$.2" BT tepatnya pada titik sounding. Titik ini diidentifikasi memilki 3 jenis lapisan batuan yaitu Clay, Sandstone, dan Limestone.
Lapisan Clay terdapat pada ketinggian $1490 \mathrm{~m}$ sampai ketinggian $1511 \mathrm{~m}$ dengan ketebalan $21 \mathrm{~m}$. Lapisan Sandstone terdapat pada ketinggian $1511 \mathrm{~m}$ sampai ketinggian $1515 \mathrm{~m}$ dengan ketebalan $4 \mathrm{~m}$ dan pada ketinggian $1479 \mathrm{~m}$ sampai ketinggian $1490 \mathrm{~m}$ dengan ketebalan $11 \mathrm{~m}$. Lapisan Limestone terdapat pada kedalaman 1458 m sampai ketinggian 1479 m dengan ketebalan $21 \mathrm{~m}$.

Titik 3 yang berada pada jarak $215 \mathrm{~m}$ dengan $01^{\circ} 11^{\prime} 26.3^{\prime \prime}$ LS dan $100^{\circ} 48^{\prime} 54.5^{\prime \prime}$ BT terdapat 4 jenis lapisan batuan yaitu, Alluvium and Sands, Clay, Sandstone dan Limestone. Lapisan Alluvium and Sands terdapat pada ketinggian $1505 \mathrm{~m}$ sampai ketinggian $1508 \mathrm{~m}$ dengan ketebalan $5 \mathrm{~m}$. Lapisan Clay terdapat pada ketinggian $1487 \mathrm{~m}$ sampai ketinggian $1508 \mathrm{~m}$ dengan ketebalan $16 \mathrm{~m}$. Lapisan Sandstone terdapat pada ketinggian $1480 \mathrm{~m}$ sampai ketinggian $1487 \mathrm{~m}$ dengan ketebalan $7 \mathrm{~m}$. Lapisan Limestone terdapat pada ketinggian $1508 \mathrm{~m}$ sampai ketinggian $1514 \mathrm{~m}$ dengan ketebalan $6 \mathrm{~m}$.

\section{B. Pembahasan}

Interpretasi data dilakukan menggunakan metode Inversi Robust Constraint data Geolistrik konfigurasi Wenner. Hasil interpretasi data menunjukkan bahwa terdapat 5 jenis lapisan batuan di daerah Jorong Koto Baru Nagari Aie Dingin Kabupaten Solok. Lapisan batuan di daerah ini terdiri dari lapisan batuan Sedimen dan lapisan batuan Beku. Lapisan batuan Sedimen terdiri dari lapisan Clay, lapisan Limestone, lapisan Alluvium and Sands dan lapisan Sandstone, sedangkan lapisan batuan beku terdiri dari lapisan Granite

Lintasan 1 memiliki rentangan nilai tahanan jenis $13,23 \Omega \mathrm{m}$ sampai $3625,90 \Omega \mathrm{m}$ dengan persentase kesalahan $2,1 \%$. Struktur penyusun lapisan bumi pada lintasan 1 terdiri dari Alluvium and Sands, Clay, Sandstone, Limestone dan Granite. Hasil interpretasi menunjukkan bahwa lapisan dekat permukaan bumi terdapat lapisan Limestone dan Granite. Lapisan berikutnya didominasi oleh lapisan Sandstone dan lapisan Clay yang berselingan dengan Sandstone dari kedalaman $62,5 \mathrm{~m}$ sampai kedalaman $65 \mathrm{~m}$. Lapisan Limestone pada kedalaman $53 \mathrm{~m}$ sampai kedalaman 62,5 $\mathrm{m}$ dan lapisan Granite pada kedalaman 103 m sampai kedalaman 108 m terdapat pada lapisan berikutnya.

Lintasan 2 memiliki rentangan nilai tahanan jenis antara 10,55 $\Omega$ m sampai 1168,19 $\Omega$ m dengan persentase kesalahan 2,3\%. Hasil Estimasi menunjukkan bahwa struktur penyusun lapisan bumi pada Lintasan 2 terdiri atas: Alluvium and Sands, Clay, Sandstone, dan Limestone. Lapisan dekat permukaan bumi terdapat lapisan Sandstone dan Limestone. Lapisan berikutnya terdapat lapisan Clay pada kedalaman $82 \mathrm{~m}$ sampai kedalaman $98 \mathrm{~m}$. Lapisan Limestone juga terdapat pada lapisan berikutnya sampai kedalaman $120 \mathrm{~m}$. 
Lintasan 3 memiliki rentangan nilai tahanan jenis berkisar antara 20,42 $\Omega \mathrm{m}$ sampai 3040,80 $\Omega \mathrm{m}$ dengan persentase kesalahan $2,2 \%$. Struktur penyusun bumi pada Lintasan 3 terdiri atas: Alluvium and Sands, Clay, Sandstone, Limestone dan Granite. Dekat permukaan bumi terdapat lapisan Sandstone dan lapisan Limestone. Lapisan berikutnya terdapat lapisan Clay, dan lapisan Alluvium and Sands yang berselingan dengan Sandstone pada kedalaman $85 \mathrm{~m}$ sampai kedalaman $94 \mathrm{~m}$. Lapisan Clay kembali terdapat pada kedalaman $94 \mathrm{~m}$ sampai kedalaman $112 \mathrm{~m}$. Lapisan Granite hanya terdapat pada kedalaman $120 \mathrm{~m}$ sampai kedalaman $122 \mathrm{~m}$.

Lintasan 4 merupakan lintasan terakhir yang memiliki rentangan nilai tahanan jenis antara 11,89 $\Omega \mathrm{m}$ sampai $1165,70 \mathrm{~m}$ dengan persentase kesalahan $3 \%$. Struktur penyusun bumi pada Lintasan 4 terdiri dari Alluvium and Sands, Clay, Sandstone dan Limestone. Dekat permukaan bumi terdapat lapisan Sandstone dan lapisan Clay. Lapisan berikutnya didominasi oleh lapisan Clay sampai kedalaman 40 m. Lapisan Sandstone kembali terdapat pada kedalaman $40 \mathrm{~m}$ sampai kedalaman $51 \mathrm{~m}$. Lapisan berikutnya didominasi oleh lapisan Limestone sampai kedalaman $72 \mathrm{~m}$. Lapisan Granite tidak terdapat pada Lintasan 4 dan lintasan ini didominasi oleh lapisan Clay.

Lapisan batuan sedimen yang terdapat di Jorong Koto Baru Nagari Aie Dingin Kabupaten Solok ada yang bersifat mudah terjadi longsor. Lapisan Clay merupakan lapisan yang mudah menyerap air namun bersifat tidak bisa meloloskan air, sehingga lapisan ini mudah sekali runtuh apabila berada di daerah lereng. Lapisan Clay dan Sandstone apabila mengalami proses pelapukan mudah menjadi tanah sehingga kedua lapisan ini rentan terhadap longsor. Berdasarkan hasil Estimasi empat lintasan pengukuran ditemukan lapisan Clay dan lapisan Sandstone dan Limestone mendominasi lapisan penyusun bawah permukaan bumi

Struktur perlapisan batuan juga dapat menyebabkan terjadinya longsor. Struktur lapisan batuan penyebab longsor ditandai dengan adanya lapisan bawah permukaan bumi yang bersifat kedap air dan lapuk ${ }^{[5]}$ Struktur penyusun lapisan bawah permukaan bumi yang terdiri dari lapisan Sandstone yang diikuti lapisan Limestone rentan akan terjadinya longsor. Hal ini karena lapisan Sandstone yang berongga akan terisi air hujan dan lapisan Limestone keras serta kedap air, sehingga lapisan Sandstone akan menjadi berat. Lapisan Clay merupakan lapisan kedap air apabila terdapat lapisan batuan yang berada tepat diatas lapisan Clay lapisan batuan tersebut akan jatuh akibat ketidakstabilan lapisan Clay di atas permukaan. Oleh sebab itu perlu adanya tindakan antisipasi untuk menghindari terjadi longsor.

\section{KESIMPULAN}

Berdasarkan hasil yang didapat pada penelitian ini, maka dapat ditarik kesimpulan yaitu struktur perlapisan batuan penyusun daerah Jorong Koto Baru Nagari Aie Dingin Kabupaten Solok menggunakan metoda Geolistrik tahanan jenis konfigurasi Wenner inversi Robust Constraint terdiri dari lima jenis lapisan batuan yaitu: Sandstone, Clay, Limestone, Granite dan Alluvium and Sands. Lapisan Sandstone, Limestone dan Clay mendominasi lapisan penyusun bawah permukaan daerah penelitian.

\section{UCAPAN TERIMA KASIH}

Penulis mengucapkan terima kasih kepada DP2M DIKTI yang telah mendanai penelitian ini melalui Pekan Kreativitas Mahasiswa (PKM) tahun 2015.Terima kasih juga kepada rekan-rekan yang telah membantu dalam pengambilan data penelitian ini serta memberikan motivasi dalam penyelesaian tugas akhir dan jurnal ini.

\section{SARAN}

Hasil penelitian ini dapat direkomendasikan kepada Badan Penanggulangan Bencana Daerah Kabupaten Solok untuk mengantisipasi terjadinya bencana longsor di Jorong Koto Baru Nagari Aie Dingin serta perlu dilakukan penelitian lanjutan dengan metode yang berbeda sebagai perbandingan dengan hasil yang telah dicapai tentang struktur batuan salah satu pemicu terjadinya longsor.

\section{DAFTAR PUSTAKA}

[1] Bappeda Kabupaten Solok. Rencana Pembangunan Daerah Kabupaten Solok 20092014.

[2] Dinas ESDM Sumatera Barat. 2015. Laporan Peninjauan Bencana Tanah Longsor Di Jorong Koto Baru Nagari Aie Dingin Kecamatan Lembah Gumanti Kabupaten Solok.

[3] Kinasti, Mekar Ageng. 2014. Pengaruh Struktur Geologi Terhadap Gerakan Tanah Di Dusun Windusari, Desa Metawana, Kecamatan Pagentan Kabupaten Banjarnegara, Provinsi Jawa Tengah. Jurnal Ilmiah MTG, Vo.7, no. 1, Januari 2014.

[4] Nurhidayati. Akmam. Harman Amir. 2015. Investigasi Bidang Gelincir Di Jorong Koto Baru Nagari Aie Dingin Kabupaten Solok Dengan Metode Geolistrik Tahanan Jenis Konfigurasi Schlumberger. Phylar of Physics, Vol. 6. Oktober 2015, hlm 73-80.

[5] Hisni Rahmi. Akmam. Mahrizal. 2015. Penyelidikan Jenis Mineral Di Jorong Koto Baru Nagari Aie Dingin Kabupaten Solok 
Dengan Metode Geolistrik Induced Polarization (IP). Phylar of Physics, Vol.6.Oktober 2015.

[6] Akmam dan Nofi Yendri Sudiar. 2013. Analisis Struktur Batuan dengan Metoda Inversi Smoothness-Constrained Least-Squared Data Geolistrik Konfigurasi Schlumberger di Universitas Negeri Padang Kampus Air Tawar. Prosiding Semirata FMIPA Universitas Lampung, 2013. Hlm 215-220.

[7] Wahid, A. 2011. Aplikasi Geolistrik Untuk Melihat Struktur Perlapisan Batuan Daerah Longsor. Media Exacta Volume 11 No.1 Januari 2011.

[8] Djauhari Noor. 2012. Pengantar Geologi. Fakultas Teknik: Universitas Pakuan.

[9] Wahid, A. 2007. Analisis Keberadaan Batuan Gamping (Limestone) Berdasarkan Nilai Resistivitasnya. Media Exacta Volume 8 No.2 Juli 2007.

[10] Akmam. Irefia Refa Dona. Rahmi Kurnia Putri. Silvia Dona Sari. 2015. Optimalisasi Inversi Least Square Dengan Inversi Occam Data Geolistrik Tahanan Jenis Konfigurasi WennerSchlumberger Untuk Estimasi di Bukitlantiak Padang Sumbar. Prosiding semirata bidang
MIPA BKS-PTN Barat Universitas Tanjungpura Pontianak, 2015. Hlm xx-Xx.

[11] Telford, W.M. Geldart, L.P, Sheriff R.E and Keys, D.A. 1990. Applied Geophysics Second Edition. USA: Cambridge University Press.

[12] Reynolds, J.M. (1997). An Introduction to Applied and Environmental Geophysics. New York: Jhon Geophysicsin Hidrogeological and Wiley and Sons Ltd.

[13] Akmam. Existensi of Spring in Batulimbak Village Simawang Kecamatan Rambatan Kabupaten Tanah Datar. Jurnal Prosiding Seminar PPD Forum HEDS 2004 Bidang MIPA ISBN 979-95726-7-3. Hlm 593-608. 2004.

[14] Akmam. 2012. Penyelidikan Reservoar Panas Bumi Menggunakan Metoda Geolistrik Tahanan Jenis Inversi 2-D Di Kenagarian Koto Anau Kabupaten Solok. Prosiding Semirata FMIPA Universitas Negeri Medan, 2013. Hlm 17-22.

[15] Loke, M.H. (2004). Tutorial: $2 D$ and $3 D$ Electrical Imaging Surveys. Di unduh dari www. geotomosoft. com. tanggal 15 November 2015 